\title{
PSYCHOLOGICAL WELL-BEING AND JOB PERFORMANCE: THE MEDIATING ROLE OF WORK ENGAGEMENT
}

Bilal ÇANKIR ${ }^{1}$

Safiye ŞAHIN ${ }^{2}$

Citation/(O: Çankır, B. and Şahin, S. (2018). Psychological well-being and job performance: the mediating role of work engagement. Hitit University Journal of Social Sciences Institute, 11(3), 2549-2560. doi: 10.17218/hititsosbil.487244

Abstract: The purpose of this study is to determine the mediating role of work engagement in the relationship between psychological well-being and job performance. The data were collected from textile workers to test the research's model. The sample of the research was composed of 322 textile workers. Psychological well-being scale, work satisfaction scale and work performance scale were used as data collection tools. The research's model was tested by structural equation analysis. It was found that the level of psychological well-being, work engagement and job performance of textile workers were below the average and low. As a result, it was determined that work engagement partially mediated the relationship between psychological well-being and job performance.

Keywords: Work Engagement, Psychological Well-Being, Job Performance.

\section{Psikolojik İyi-Oluş ve İş Performansı: Çalışmaya Tutkunluğun Aracı Rolü}

Atıf/(O: Çankır, B. ve Şahin, S. (2018). Psikolojik iyi-oluş ve iş performansı: çalışmaya tutkunluğun aracı rolü, Hitit Üniversitesi Sosyal Bilimler Enstitüsü Dergisi, 11(3), 2549-2560. doi: 10.17218/hititsosbil.487244

Özet: $\mathrm{Bu}$ çalışmanın amacı, psikolojik iyi oluşun iş performansına etkisinde çalışmaya tutkunluğun aracı rolünü belirlemektir. Bu doğrultuda oluşturulan araştırma modelini test etmek amacıyla tekstil çalışanlarından veri toplanmıştır. Araştırmanın örneklemini 322 tekstil çalışanı oluşturmuştur. Veri toplama aracı olarak, literatürde daha önce kullanılan, geçerlilik ve güvenirlik analizleri yapılmış olan psikolojik iyi oluş ölçeği, çalışmaya tutkunluk ölçeği ve iş performansı ölçeği kullanılmıştır. Araştırma modeli yapısal eşitlik analizi ile test edilmiştir. Sonuç olarak, psikolojik iyi oluşun iş performansına etkisinde çalışmaya tutkunluğun kısmi aracı rolü olduğu belirlenmiştir.

Anahtar Kelimeler: Çalışmaya Tutkunluk, Psikolojik İyi Oluş, İş Performansı.

\section{INTRODUCTION}

Job performance is very important in environments with fierce competition and the employees displaying high job performance is the fundamental factor to maintain the quality of service. The enterprises need the personnel displaying high job performance to reach their goals. Therefore, there have been numerous studies for determination of variables interacting with job performance (Johnson, 2003; Motowidlo, 2003, p. 92.).

Work engagement is one of the constructs that are closely associated with job performance and have attract interest of many researchers (Schaufeli et al., 2002, p. 74; Rich, Lepine and Crawford,

Makale Gelis Tarihi: 24.11.2018 Makale Kabul Tarihi: 25.12.2018

1 Assist. Prof., Istanbul Medeniyet University, Faculty of Political Sciences, Department of Management, bilal.cankir@medeniyet.edu.tr, http://orcid.org/0000-0001-5126-8769

2 Corresponding Author, Assist. Prof., Istanbul Medeniyet University, Faculty of Health Sciences, Health Care Management, safiye.sahin@medeniyet.edu.tr, http://orcid.org/0000-0003-1734-9586 
2010; Christian, Garza and Slaughter, 2011, p. 64). Work engagement emerges when the personnel cope with the work demands through their personal and organizational resources and perform with high energy (Bakker, Hakanen, Demerouti and Xanthopoulou, 2007, p. 280). For this reason, psychological well-being is closely associated with work engagement. Studies have revealed that while burnout is associated with negative feelings, work engagement is associated with positive feelings such as optimism, hope, enthusiasm (Bakker, Hakanen, Demerouti and Xanthopoulou, 2007; Bakker, Emmerik and Euwena, 2006; Hallberg, Johansson and Schaufeli, 2007, p. 135).

Starting from this, the personnel who feel well psychologically are foreseen to be engaged with work and have high job performance. Literature also involves studies indicating that psychological well-being is associated with work engagement and high job performance. However, the number of the related studies is limited and there has been no study investigating the mediator role of work engagement in this relationship. The present study will contribute to the literature by providing empirical evidences primarily for the relationship between psychological well-being and job performance. This research model will also be tested on textile workers. Such study on textile workers has not been found previously. With this aspect, it will also contribute to the literature about validity of this model in different sample.

\section{PSYCHOLOGICAL WELL-BEING}

Well-being is defined as the state of having no anxiety, uneasiness, depression, and other psychological disorders in individual's life (Ryff, 1995, p. 99). Well-being has become the subject of researches with different variables as the indicator for satisfaction of people since the 1700s (Ryff and Keyes, 1995). The meaning of life, autonomy; competence, context which are three basic psychological needs according to the self-determination theory; satisfaction with life about different areas and overall of life; and happiness have been stated as indicators of well-being (Samman, 2007; Çankır and Yener, 2017, p. 228). Psychological well-being is generally defined as efficiency of psychological functioning of an individual (Gechman and Wiener, 1975; Jamal and Mitchell, 1980; Martin, 1984; Sekaran, 1985; Wright and Cropanzano, 2000, p. 84).

There are two perspectives concerning the well-being in the literature as subjective (hedonic) and psychological (eudaimonic) approaches. Subjective well-being is the approach focusing on descriptions of well-being concerning avoidance from aches and pain and obtaining satisfaction and on happiness occurring along with the 1950s (Telef, 2013, p. 374). Psychological well-being is the approach emerging in the 1980s. Deci and Ryan (Deci and Ryan, 2008, p. 73) defined psychological well-being as felicity in private and work life of individual and the state of optimal efficiency. Psychological well-being means that life goes on well and person feels good and carries out works impressively (Huppert, 2009; Çankır and Semiz, 2018, p. 59).

Ryan and Deci (2001) claimed that the meaning of life can be determined by three basic needs of individuals according to the self-determination theory. These three basic psychological needs called as competence, autonomy, and context (relatedness) have been suggested to improve wellbeing of individuals by increasing their power to give the meaning to life. Ryan and Deci (2001) provides intercultural measurement indirectly in evaluation of well-being by attributing the meaning of life to the self-determination theory. Because, three basic psychological needs indicated by self-determination theory are considered as general need of all populations (Çankır and Yener, 2017).

\section{WORK ENGAGEMENT}


Work engagement is described as a mental state in which the personnel works vividly, focused, and with feelings of commitment (Schaufeli and Bakker, 2003; Çankır, 2016). Work engagement is the indicator for the fact that the personnel feel themselves happy, healthy, good, and peaceful (Poon, 2013). The personnel engaged to work participates individually for their organizations to reach their goals. Individual participation signifies that each individual contributes the organization (Altunel, Koçak and Çankır, 2015).

Work engagement has three dimensions including vigor, dedication, and absorption as stated in the description. Vigor is defined as having high energy level, mental comfort during working, being disposed to show effort, and being resistant to difficulties (Schaufeli, et al., 2002). Individual feels satisfied and works with pleasure when carrying out jobs in this dimension. The dimension of dedication means that individual works gladly with the feeling to challenge difficulties and show high level of participation in the work (Jenaro, et al., 2011). Every employee faces difficulties when working. However, a person dedicated to work never hesitates to show patience and to make extra effort to overcome difficulties according to this dimension. The dimension of absorption signifies that individual pays attention to work completely, is glad to engage in the work, and has difficulty in leaving job (Çankır, 2016, p. 14). According to another definition, employee is dedicated to work, does not recognize how the time passes while working, and works gladly and selflessly (Bakker, 2011). This dimension does not involve bad sides of workaholism - especially such as the balance between work and private lives- on the other hand, it reflects the satisfaction with work life to family life.

Recent studies conducted on psychological well-being and work engagement have shown that burnout, work engagement, workaholism, and job satisfaction are involved among the indicators of psychological well-being (Bakker and Oerlemans, 2011; Mäkikangas, et al., 2015). In their study, Shimazu et al., (2009, 2012) investigated the relationship between psychological well-being and work engagement and found a significant and positive correlation between both variables. In another study, psychological well-being and work engagement were examined and psychological well-being was determined to have a significant and positive effect on work engagement (Brunetto, et al., 2012). Accordingly, the first hypothesis of the study;

H1: Psychological well-being has a positive and significant impact on work engagement.

\section{JOB PERFORMANCE}

Job performance is defined as individual behaviors that contribute to achieve organizational goals (Van Scotter and Motowidlo, 1996, p. 525). According to another definition, it is the set of behaviors displayed by employee to contribute directly or indirectly to organization in accordance with goals of the organization (Rich, Lepine and Crawford, 2010, p. 619).

Job performance is very important for the organizations. Additionally, high job performance is also important for employees because it provides positive benefits such as higher income, a better carrier, and a better social reputation (Sonnentag and Freese, 2002, p. 4). Therefore, many studies have been conducted for determination of variables interacting with job performance (Johnson, 2003; Motowidlo, 2003).

There are also studies explaining the correlation between psychological well-being and performance. In a study on 347 employees of service industry, it was determined that there was a significant and positive correlation between psychological well-being and performance (Holman, Chissick, and Totterdell, 2002). As a result of a study on 109 managers, the effect of psychological well-being on performance was examined and it was reported that psychological well-being had a 
significant and positive effect on performance (Wright, Cropanzano, and Bonett, 2007). Starting from this, the second hypothesis of the study is as follows;

H2: Psychological well-being has a positive and significant impact on job performance.

The correlation between work engagement and performance was also examined by numerous researchers. A study revealed a significant and positive correlation between work engagement and performance (Bakker, 2011, p. 267). In a study conducted in Turkey, it was concluded that there was a significant and positive correlation between work engagement and performance (Caymaz, Erenel, and Gürer, 2013, 139). In another study, the correlation among worker performance and financial performance and work engagement was investigated and a positive and significant correlation was found between both variables (Çankır and Semiz, 2018, p. 62). Accordingly, the third hypothesis of the study is as follows;

H3: Work engagement has a positive and significant impact on work job performance.

It is assumed in this study that psychological well-being will improve work engagement and will increase job performance through work engagement. Figure 1 shows the model of the study. Upon the literature review, there is no study on the mediator role of work engagement in the relationship between psychological well-being and job performance. According to result of a similar study, a significant and negative correlation was found among psychological ill-being (state of disorderhealth) and work engagement and performance (Jenaro, et al., 2011). Accordingly, the fourth hypothesis of the study is as follows;

H4: Work engagement has a mediator role in the relationship between psychological well-being and job performance.

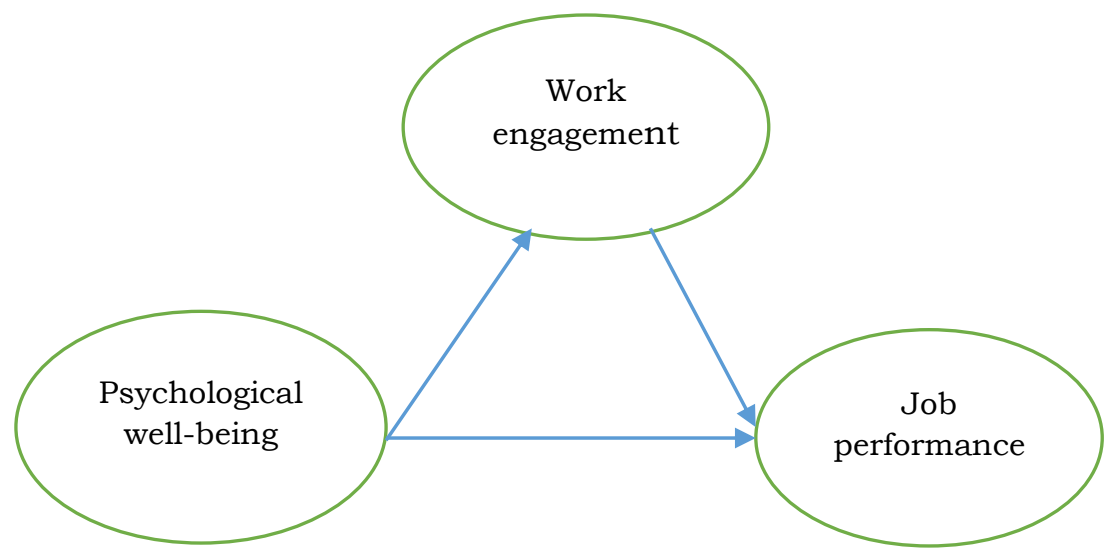

Figure 1. Study's Model

\section{METHODS}

\subsection{Sample and Procedure}

We collected data with an online survey in 2016. We sent survey link to participants with an email. The sample of the study consisted of 322 employees and managers working in textile sector in Istanbul, who agreed to take part in this research. We present socio-demographic and job characteristics of sample in Table 1 . Of the respondents, $51.6 \%$ were female and $58.7 \%$ were single. $38.5 \%$ completed bachelor's degree and $44.7 \%$ completed high school degree. The age of the respondents varied between 18-60 years. Of the respondents, $14.9 \%$ had lower than 5 months' organizational tenure and $11.8 \%$ had higher than 10 years' organizational tenure. 
Table 1: Socio-Demographic and Job Characteristics of Sample

\begin{tabular}{|c|c|c|c|c|c|c|c|}
\hline \multicolumn{2}{|c|}{$\begin{array}{l}\text { Socio-demographic and } \\
\text { job characteristics }\end{array}$} & \multirow{2}{*}{$\begin{array}{l}\mathbf{N} \\
156\end{array}$} & \multirow{2}{*}{$\begin{array}{l}\% \\
48.4\end{array}$} & \multicolumn{2}{|c|}{$\begin{array}{l}\text { Socio-demographic and } \\
\text { job characteristics }\end{array}$} & \multirow{2}{*}{$\begin{array}{l}\mathbf{N} \\
124\end{array}$} & \multirow{2}{*}{$\begin{array}{l}\% \\
38.5\end{array}$} \\
\hline \multirow{3}{*}{ Gender } & Male & & & \multirow{6}{*}{ Age } & $18-24$ & & \\
\hline & Female & 166 & 51.6 & & $25-31$ & 91 & 28.3 \\
\hline & Total & 322 & 100.0 & & $32-38$ & 58 & 18.0 \\
\hline \multirow{3}{*}{$\begin{array}{l}\text { Marital } \\
\text { Status }\end{array}$} & Married & 143 & 44.4 & & $39-45$ & 38 & 11.8 \\
\hline & Single & 179 & 55.6 & & $>46$ & 11 & 3.4 \\
\hline & Total & 322 & 100.0 & & Total & 322 & 100.0 \\
\hline \multirow{4}{*}{ Education } & $\begin{array}{l}\text { Primary } \\
\text { school }\end{array}$ & 54 & 16.8 & \multirow{8}{*}{ Tenure } & $<5$ months & 48 & 14.9 \\
\hline & High school & 144 & 44.7 & & $\begin{array}{l}6 \text { months- } 1 \\
\text { year }\end{array}$ & 47 & 14.6 \\
\hline & $\begin{array}{l}\text { Bachelor's } \\
\text { degree }\end{array}$ & 124 & 38.5 & & $1-2$ years & 63 & 19.6 \\
\hline & Total & 322 & 100.0 & & 3-4 years & 61 & 18.9 \\
\hline \multirow{4}{*}{ Position } & $\begin{array}{l}\text { Senior } \\
\text { manager }\end{array}$ & 38 & 11.8 & & 5-7 years & 44 & 13.7 \\
\hline & $\begin{array}{l}\text { Mid-level } \\
\text { manager }\end{array}$ & 65 & 20.2 & & $8-10$ years & 21 & 6.5 \\
\hline & Staff & 219 & 68.0 & & $>10$ years & 38 & 11.8 \\
\hline & Total & 322 & 100.0 & & Total & 322 & 100.0 \\
\hline
\end{tabular}

\subsection{Measures:}

Respondents rated their psychological well-being using an 8-item scale which was developed by Diener, Wirtz, Biswas-Diener, Tov, Kim-Prieto, Choi, and Oishi (2009) with a 5-point Likert scale $(1=$ strongly disagree and $5=$ strongly agree). A sample item was "I lead a purposeful and meaningful life" $(a=.86)$. This scale was adopted to Turkish by Telef $(2013)(a=0.86)$.

Then, we used very short form of Utrecht Work Engagement Scale (UWES-3) to measure respondents' level of work engagement (Schaufeli, et al., 2017). We asked participants to rate their answers by choosing $1=$ strongly disagree to $5=$ strongly agree. Sample item included: "At my work, I feel bursting with energy". We adopted to Turkish UWES-3 in the scope of this study. Finally, to measure job performance, we used performance scale four items by Kirkman and Rosen, (1999) and Sigler and Pearson, (2000) adapted by Turkish by Çöl (2011).

\subsection{Data Analysis}

We used SPSS 23 and AMOS 23 programs in the analysis of the research data. The AMOS (Analysis of Moment Structures) program is a Structural Equation Model (SEM) program (Arbuckle, 1997). We used as fit indices root mean square error of approximation (RMSEA), root mean square residual (RMR), comparative fit index (CFI) and Tucker-Lewis index (TLI) to represent 
model fit (46). Values for RMSEA and RMR below 0.08 and for other indices above 0.90 were considered to indicate a good fit (46). We followed Baron and Kenny's (1986) approach to test the mediation model. In order to validate measures, we performed Confirmatory Factor Analysis (CFA).

\section{FINDINGS}

First, in order to examine the distinctiveness of the study variables, we conducted CFA's to compare the fit of our hypothesized measurement model to alternative models. The hypothesized three-factor measurement model (psychological well-being, work engagement and job performance) as three distinct factors, for which we loaded each item onto its respective higher order factor. We compared the hypothesized three-factor measurement model with the two-factor measurement model (work engagement and job performance as a single factor and psychological well-being) and a single-factor measurement model (all items of psychological well-being, work engagement and job performance loaded on a single factor). We showed the results in Table 2. Chi-square difference tests indicated that the hypothesized three-factor measurement model fit the data well than the alternative models. These results provided support for psychological wellbeing, work engagement and job performance as distinct constructs in the present study.

Table 2. Fit indices of alternative factor models $(\mathrm{N}=322)$

\begin{tabular}{|c|c|c|c|c|c|c|c|c|c|}
\hline Model & $\mathbf{X}^{2}$ & $d f$ & RMSEA & CFI & TLI & RMR & Comparison & $\Delta \mathbf{X}^{2}$ & $\Delta d f$ \\
\hline $\begin{array}{l}\text { M1: Three- } \\
\text { factor } \\
\text { model }\end{array}$ & 281 & 87 & 0.08 & 0.93 & 0.91 & 0.05 & - & - & - \\
\hline $\begin{array}{l}\text { M2: Two- } \\
\text { factor } \\
\text { model }\end{array}$ & 392 & 89 & 0.10 & 0.89 & 0.87 & 0.06 & M2-M1 & $111^{* *}$ & 2 \\
\hline $\begin{array}{l}\text { M3: } \\
\text { Single- } \\
\text { factor } \\
\text { model }\end{array}$ & 698 & 90 & 0.14 & 0.79 & 0.74 & 0.07 & M3-M1 & $417^{* *}$ & 3 \\
\hline
\end{tabular}

$* * p<.01$

We present the descriptive statistics, including the means, standard deviations, internal consistency reliabilities, and correlations among all study variables in Table 3 . As seen in the table 3 , the mean of psychological well-being was $2.09 \pm 0.7$, the mean of work engagement was $2.26 \pm 0.88$ and the mean of job performance was 2.05 \pm 0.75 . Psychological well-being was significantly correlated with work engagement $(r=0.61, p<0.01)$ and job performance $(r=0.62$, $\mathrm{p}<0.01)$. There was also significant correlation between work engagement and job performance $(\mathrm{r}$ $=0.63, \mathrm{p}<0.01)$.

Table 3. Means, Standard Deviations, Reliabilities, and Correlations between Study Variables

\begin{tabular}{lllllll}
\hline \multicolumn{1}{c}{ Variable } & $\mathbf{N}$ & $\mathbf{M}$ & $\mathbf{S S}$ & $\mathbf{1}$ & $\mathbf{2}$ & $\mathbf{3}$ \\
\hline $\begin{array}{l}\text { Psychological well- } \\
\text { being }\end{array}$ & 322 & 2.09 & 0.70 & $(0.89)$ & & \\
2 Work engagement & 322 & 2.26 & 0.88 & $0.614^{* *}$ & $(0.82)$ & \\
3 Job performance & 322 & 2.05 & 0.75 & $0.624^{* *}$ & $0.634^{* *}$ & $(0.85)$ \\
\hline
\end{tabular}


${ }^{*} p<.05 .{ }^{* *} p<.01$. Coefficients alpha for psychological well-being, work engagement and job performance are along the diagonal in the parenthesis.

We tested the mediating role of work engagement in the effect of psychological well-being on job performance. As a result of testing research's model, psychological well-being affected job performance directly and indirectly via the work engagement (partial mediating) Fit indices indicated that the research's model showed a good fit with data $(\mathrm{x} 2=281.29, \mathrm{df}=87, \mathrm{p}=0.0001$, RMR=0.05, RMSEA=0.08, TLI=0.91, CFI=0.93).

According to Figure 2, psychological well-being predicted work engagement (unstandardized $\beta=$ $0.86 ; p<0.01$ ) and job performance (unstandardized $\beta=0.35 ; \mathrm{p}<.001$ ) significantly. Similarly, work engagement predicted job performance significantly (unstandardized $\beta=0.35 ; \mathrm{p}<0.01$ ). So, H1, $\mathrm{H} 2$ and $\mathrm{H} 3$ were supported.

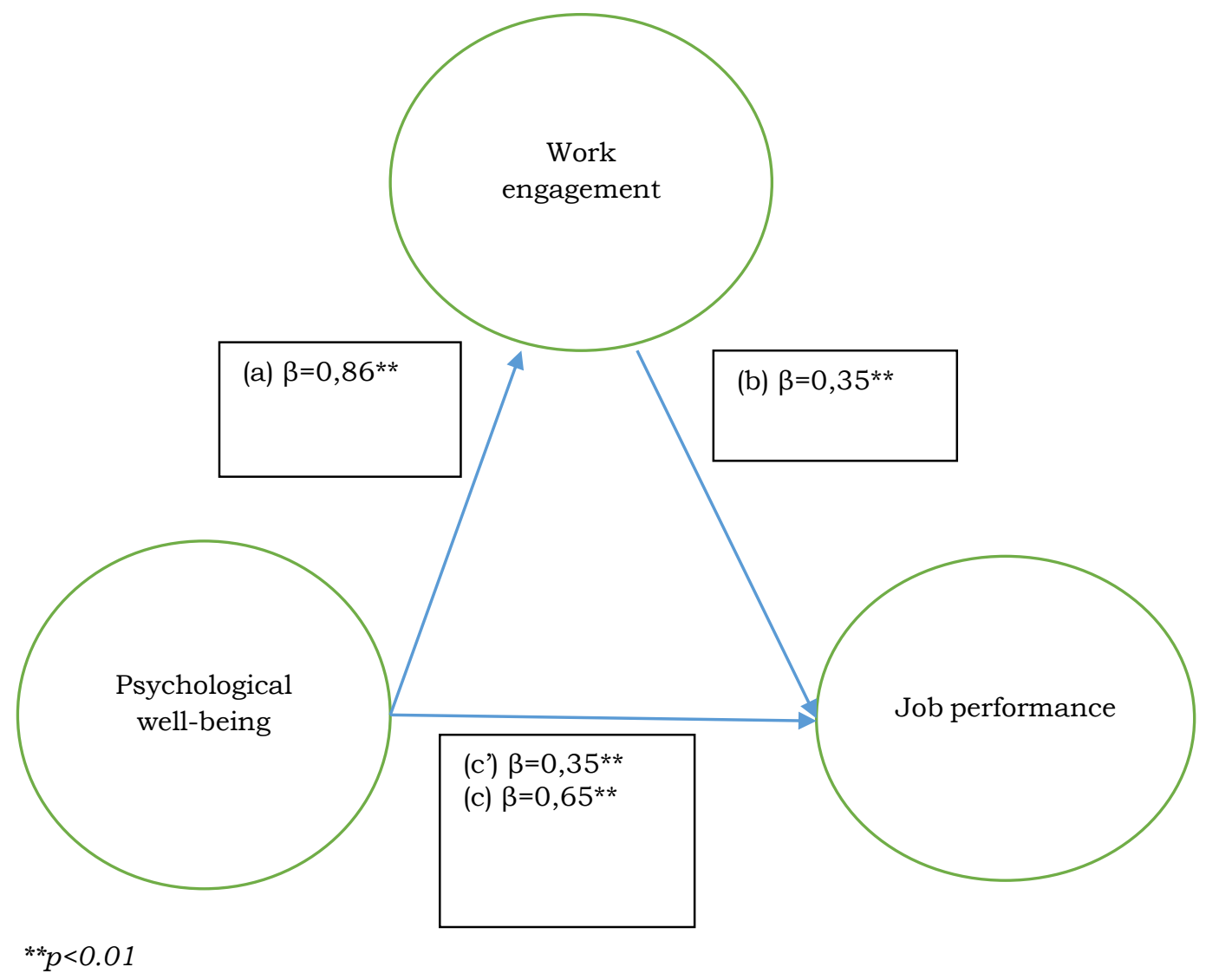

Figure 2. Path Coefficients of Research's Model

We showed Sobel test results, direct, indirect and total effect of psychological well-being on job performance through work engagement in Table 4. According to these results, work engagement partially mediated the relationship between psychological well-being and job performance. So, H4 was supported. 
Table 4. Sobel Test Results and Direct, Indirect, Total Effects of Psychological Well-Being on Job Performance

\begin{tabular}{lr}
\hline & Job Performance \\
\hline Sobel Z value & 5.05356429 \\
$\boldsymbol{p}$ & 0.00000043 \\
Direct effect & 0.35 \\
Indirect effect & 0.30 \\
Total effect & 0.65 \\
\hline
\end{tabular}

\section{DISCUSSION}

The present study was conducted to determine the mediator role of work engagement in the effect of psychological well-being of textile workers on their job performance. According to the results of the study, it was determined that work engagement had a partial mediator role in the relationship between psychological well-being and job performance. It is foreseen that workers who feel well and happy psychologically will display high job performance. The present study empirically proves that psychological well-being affects job performance. According to the result of the present study, psychological well-being is closely associated with work engagement and increases job performance through work engagement.

It was determined from the results of the study that psychological well-being, work engagement, and job performance levels of textile workers were below the average and low. In the study conducted by Siu (2002) on textile workers in China, a 6-point Likert type psychological wellbeing scale with 12 items was used (Siu, 2002). We converted the total score of textile workers from psychological well-being scale used in the study by Siu (2002) to a 5-point Likert scale. Psychological well-being of textile workers in China was moderate with 3.24 \pm 0.6 .

In parallel to the results of present study, Brunetto et al., (2012) found a positive significant correlation between psychological well-being and work engagement $(r=0.69, p<0.001)$ (Brunetto, et al., 2012). A similar correlation was found between psychological well-being and work engagement in the present study as well $(\mathrm{r}=0.61, \mathrm{p}<0.01)$. Based on these results, it can be asserted that there is a strong correlation between psychological well-being and work engagement. Likewise, there is also a significant correlation between psychological well-being and job performance (Holman, Chissick, and Totterdell, 2002; Wright, Cropanzano, and Bonett, 2007). There are a great number of studies proving that there is a positive and significant correlation between work engagement and job performance (Rich, Lepine and Crawford, 2010, p. 617; Christian, Garza and Slaughter, 2011). Therefore, psychological well-being of the personnel is closely associated with their work engagement and displaying high job performance. For this reason, it is important for managers to create an organization environment that will ensure employees to feel psychologically well.

\section{CONCLUSION}

In today's rapidly changing and competitive working conditions, organizations are required to play important roles in ensuring work engagement. Because, work engagement constitutes many desired results such as psychological well-being and showing positive attitudes towards employees' work, performing above expectations, identifying with the organization and contributing to the improvement of organizational efficiency. In order for organizations to compete effectively, it is not enough to provide only high qualified employees. At the same time, it is 
necessary to ensure that qualified employees are given the necessary opportunities to use all their skills and they are engaged at work. Work engagement provides various positive results at the individual and organizational level. When evaluated on an individual basis, work engagement creates positive feelings such as self-employment. These positive emotions affect the employee's quality of work, the ability to use their skills and creativity, and also these individual results reflect on the organizational results. In other words, the individual results of the work engagement affect the organizational results indirectly.

\section{REFERENCES}

Altunel, M. C., Kocak, O. E., and Çankir, B. (2015). The effect of job resources on work engagement: A study on academicians in Turkey. Educational Sciences: Theory and Practice, 15(2), 409-417.

Arbuckle, J. (1997). Amos Users' Guide, version 3.6. Marketing Division, SPSS Incorporated.

Bakker, A. B. (2011). An evidence-based model of work engagement. Current Directions in Psychological Science, 20(4), 265-269.

Bakker, A. B., Emmerik, H., Euwena, M. C. (2006). Crossover of burnout and engagement in work teams. Work and Occupations, 33(4), 464-489.

Bakker, A. B., Hakanen, J. J., Demerouti, E., and Xanthopoulou, D. (2007). Job resources boost work engagement, particularly when job demands are high. Journal of Educational Psychology, 99(2), 274-284.

Bakker, A.B., and Oerlemans, W. (2011). Subjective psychological well-being in organization”, In K.S Cameron and G.M. Spreitzer (Eds), The Oxford Handbook of Positive Organizational Scholarship (pp. 178-189). New York: Oxford University Press. doi: 10.1093/oxfordhb/9780199734610.013.0014.

Baron, R. M., and Kenny, D. A. (1986). The moderator-mediator variable distinction in social psychological research: Conceptual, strategic, and statistical considerations. Journal of Personality and Social Psychology, 51(6), 1173-1182.

Brunetto, Y., Teo, S. T., Shacklock, K., and Farr- Wharton, R. (2012). Emotional intelligence, job satisfaction, well- being and engagement: Explaining organisational commitment and turnover intentions in policing. Human Resource Management Journal, 22(4), 428-441.

Çankır B., Semiz Çelik D. (2018), Çalışan performansı ve mali performans: pozitif ses çıkarma, psikolojik iyi-oluş ve çalışmaya tutkunluk ile ilişkileri ve otel işletmeleri örneği”, İstanbul Gelişim Üniversitesi Sosyal Bilimler Dergisi, 5(2), 54-67.

Çankır, B. (2016). "Çalışmaya tutkunluk ve tükenmişliğin örgütsel vatandaşlık davranış1 üzerindeki etkisi ve bir uygulama”, Doktora Tezi. İstanbul: İstanbul Üniversitesi.

Çankır, B., and Yener, S., 2017, İş’te Pozitif Davranış. Çizgi Kitapevi: Konya.

Caymaz, E., Erenel, F., and Gürer, B. (2013). Liderlik karizmas1, adanmışlik ve gruba aidiyetin gönüllü çalışma performansına etkileri: AKUT Arama Kurtarma Derneği örneği. Journal of Human Sciences, 10(1), 129-147. 
Christian, M. S., Garza, A. S., and Slaughter, J. E. (2011). Work engagement: A quantitative review and test of its relations with task and contextual performance. Personnel Psychology, 64(1), 89-136.

Çöl, G. (2011). Algılanan güçlendirmenin iş gören performansı üzerine etkileri. Doğuş Üniversitesi Dergisi, 9(1), 35-46.

Deci, E. L., and Ryan, R. M. (2008). Self-determination theory: A macrotheory of human motivation, development, and health. Canadian psychology, 49(3), 182.

Diener, E., Wirtz, D., Biswas-Diener, R., Tov, W., Kim-Prieto, C., Choi, D.-W., and Oishi, S. (2009). New measures of well-being. In E. Diener (Ed.), Social indicators research series: Vol. 39. Assessing well-being: The collected works of Ed Diener (pp. 247-266). New York, NY, US: Springer Science + Business Media.

Gechman, A., and Wiener, Y. (1975). Job involvement and satisfaction as related to mental health and personal time devoted to work. Journal of Applied Psychology, 60, 521-523.

Hallberg, U. E., Johansson, G., and Schaufeli, W. B. (2007). Type A behavior and work situation: Associations with burnout and work engagement. Scandinavian Journal of Psychology, 48, 135-142.

Holman, D., Chissick, C., and Totterdell, P. (2002). The effects of performance monitoring on emotional labor and psychological well-being in call centers. Motivation and Emotion, 26(1), 57-81.

Huppert, F. A. (2009). Psychological well- being: Evidence regarding its causes and consequences. Applied Psychology: Health and Well- Being, 1(2), 137-164.

Jamal, M., and Mitchell, V. F. (1980). Work, nonwork, and mental health: A model and a test. Industrial Relations, 19, 88-93.

Jenaro, C., Flores, N., Orgaz, M. B., and Cruz, M. (2011). Vigour and dedication in nursing professionals: towards a better understanding of work engagement. Journal of Advanced Nursing, 67(4), 865-875.

Johnson, E. P. (2003). Appropriating Blackness: Performance and the politics of authenticity. Duke University Press.

Kirkman, B. L., and Rosen, B. (1999). Beyond self-management: Antecedents and consequences of team empowerment. Academy of Management Journal, 42(1), 58-74.

Kline, R. B. (2015). Principles and practice of structural equation modeling. Guilford publications.

Mäkikangas, A., Rantanen, J., Bakker, A. B., Kinnunen, M. L., Pulkkinen, L., and Kokko, K. (2015). The circumplex model of occupational psychological well-being: Its relation with personality. Journal for Person-Oriented Research, 1.

Martin, T N. (1984). Role stress and inability to leave as predictors of mental health. Human Relations, 37, 969-983.

Motowidlo, S. J. (2003). Job performance. Handbook of Psychology.

Poon, J. M. (2013). Relationships among perceived career support, affective commitment, and work engagement. International Journal of Psychology, 48(6), 1148-1155. 
Rich, B. L., Lepine, J. A., and Crawford, E. R. (2010). Job engagement: Antecedents and effects on job performance. Academy of Management Journal. 53(3), 617-625.

Ryan, R. M., and Deci, E. L. (2001). On happiness and human potentials: A review of research on hedonic and eudaimonis well-being. Annual Review of Psychology, 52, 141-166.

Ryff, C. D. (1995). Psychological well-being in adult life. Current Directions in Psychological Science, 4, 99-104.

Ryff, D. C., and Keyes, C. L. M., 1995, The Structure of Psychological Well Being Revisited. Journal of Psychological and Social Psychology, 69(4), 719-727.

Samman, E. (2007). Psychological and Subjective wellbeing: A proposal for internationally comparable indicators. Oxford Development Studies.

Schaufeli, W. B., and Bakker, A. B. (2003). Utrecht work engagement scale: Preliminary manual. Occupational Health Psychology Unit, Utrecht University, Utrecht.

Schaufeli, W. B., Salanova, M., González-Romá, V., and Bakker, A. B. (2002). The measurement of engagement and burnout: A two sample confirmatory factor analytic approach. Journal of Happiness Studies, 3(1), 71-92.

Schaufeli, W. B., Shimazu, A., Hakanen, J., Salanova, M., and De Witte, H. (2017). An Ultra-Short Measure for Work Engagement: The UWES-3 Validation Across Five Countries. European Journal of Psychological Assessment.

Sekaran, U. (1985). The paths to mental health: An exploratory study of husbands and wives in dual-career families. Journal of Occupational Psychology, 58, 129-137.

Shimazu, A., and Schaufeli, W. B. (2009). Is workaholism good or bad for employee psychological well-being? The distinctiveness of workaholism and work engagement among Japanese employees. Industrial health, 47(5), 495-502.

Shimazu, A., Schaufeli, W. B., Kubota, K., and Kawakami, N. (2012). Do workaholism and work engagement predict employee psychological well-being and performance in opposite directions?, Industrial health, 50(4), 316-321.

Sigler, T. H., and Pearson, C. M. (2000). Creating an empowering culture: examining the relationship between organizational culture and perceptions of empowerment. Journal of Quality Management, 5(1), 27-52.

Siu, O. L. (2002). Occupational stressors and well- being among Chinese employees: The role of organizational commitment. Applied Psychology, 51(4), 527-544.

Sonnentag, S., and Frese, M. (2002). Performance Concepts and Performance Theory. In S. Sonnentag (Ed.) Psychological Management of Individual Performance (p.4-25). John Wiley and Sons, Ltd.

Telef, B. B. (2013). Psikolojik iyi oluş ölçeği: Türkçeye uyarlama, geçerlik ve güvenirlik çalışması. Hacettepe Üniversitesi Eğitim Fakültesi Dergisi, 28(3).

Van Scotter, J.R. and Motowidlo S.J. (1996). Interpersonal facilitation and job dedication as separate facets of contextual performance. Journal of Applied Psychology, 81, 525-531.

Wright, T. A., and Cropanzano, R. (2000). Psychological well-being and job satisfaction as predictors of job performance. Journal of Occupational Health Psychology, 5(1), 84. 
Wright, T. A., Cropanzano, R., and Bonett, D. G. (2007). The moderating role of employee positive well-being on the relation between job satisfaction and job performance. Journal of Occupational Health Psychology, 12(2), 93. 